Research Article

\title{
Neocosmospora rubicola: An Unrecorded Pathogen from Pakistan Causing Potato Stem Rot
}

\author{
Muhammad Riaz ${ }^{1 *}$, Naureen Akhtar ${ }^{1}$, Salik Nawaz Khan ${ }^{1}$, Muhammad Shakeel ${ }^{1,2}$ and Ateeq Tahir ${ }^{1}$
}

${ }^{1}$ Institute of Agricultural Sciences, University of the Punjab, Lahore, Pakistan; ${ }^{2}$ Agriculture Research Institute (ARI), Saraib, Quettta, Pakistan.

Abstract | Potato (Solanum tuberosum) is one of the important staple crops over the world. Potato crop is threatening by a number of biotic stresses which not only affect plant health and yield but also the quality of the produce. Among biotic diseases, fungal stem and tuber rot are the most common diseases that cause significant loss in potato production in Punjab province, Pakistan. Neocosmospora rubicola was found as a new pathogen causing stem rot of potato in the potato growing area of district Kasur. Symptoms of the N. rubicola infected potato plants were necrotic stem lesions near the collar region. Causal organism was isolated from the infected tissues, purified and identified on the basis of morphological characters, nucleotide sequences of internal transcribed spacer region (ITS) and partial beta tubulin gene. Phylogenetic analysis was also conducted to determine the phylogenetic relationship of this species with other reported species of this genus. Pathogenic potential of the isolate was verified by artificially inoculating the spores of pathogen in healthy plants. Appearance of same symptoms and re-isolation of N. rubicola from infected tissue confirmed Koch's pathogenicity postulates. Association of $N$. rubicola causing stem rot in potato is never reported before in Pakistan.

Received | March 12, 2019; Accepted | July 27, 2020; Published | August 14, 2020

*Correspondence | Muhammad Riaz, Institute of Agricultural Sciences, University of the Punjab, Lahore, Pakistan; Email: mriaz.iags@gmail.com Citation | Riaz, M., N. Akhtar, S.N. Khan, M. Shakeel and A. Tahir. 2020. Neocosmospora rubicola: An unrecorded pathogen from Pakistan causing potato stem rot. Sarbad Journal of Agriculture, 36(3): 906-912.

DOI | http://dx.doi.org/10.17582/journal.sja/2020/36.3.906.912

Keywords | Potato stem rot, Neocosmospora rubicola, Morphology and physiology, Pathogenic potential, Phylogenetic analysis

\section{Introduction}

$\mathrm{P}$ otato (Solanum tuberosum L.) is a tuber crop which is ranked as the world's fourth largest food crop after wheat, rice and corn (Iqbal et al., 2019). Potato tubers are rich in carbohydrates, vitamins, minerals and other phytochemicals that contribute in human health and reduce health related risks of consumers (King and Slavin, 2013). Productivity of potato crop is affected by a large number of insects, viral, bacterial and fungal pathogens. Important potato fungal diseases in Pakistan are early and late blight, Fusarium rot and wilt, powdery mildew, black scurf, wart and Rbizoctonia canker (Majeed and
Muhammad, 2018; Shahzadi et al., 2020). N. rubicola has been reported as a causative agent of stem rot of Hylocereus costaricensis in China (Zheng et al., 2018) and root rot of Glycyrrbiza uralensis in Korea (Kim et al., 2017). This fungus is also known to cause root rot in pear plant (Tang et al., 2017).

In the Genus Neocosmospora, approximately 900 species are including and nearly 100 of plant families act as spanning host of these strains. Previously, the species of Neocosmospora were included in the genus of Fusarium. However, Nalim et al. (2011) placed these species in the Fusarium solani group as members of Neocosmospora. But later, phylogenetic analyses of 
DNA sequence data from six loci (act, ITS, LSU, rpb1, tef1 and tub), with integrated morphological characterizations of Neocosmospora, it is recognized as separate genus (Hirooka, et al., 2012). Ubiquitously, the species of this genus survive extensively in living and dead plants, soil, air, and water (Lombard et al., 2015).

Hence, the most popular theory for mode of action of Neocosmospora species reveals that they inhibit eukaryotic cells, by different ways including suppression of protein, DNA, and RNA biosynthesis, restraining mitochondrial function, cell division and membrane function. (Karlovsky et al., 2016). The aim of this study was updating the statistics of disease distribution and varietal susceptibility trend in various potato growing regions of Punjab, Pakistan and Designing of comprehensive strategies for integrated disease management (IDM).

\section{Materials and Methods}

During a survey conducted in April 2017 and 2018, potato fields in Kot Radha Kishan (31 $11^{\circ} 21 \mathrm{~N}$ $\left.74^{\circ} 5^{\prime} 59 \mathrm{E}\right)$, District Kasur, in Punjab province, Pakistan, to monitor potato rot diseases were found to be infected with unknown disease. A total of ten fields randomly selected from five villages of district Kasur. To ensure unbiased data, recording of the field scouting was made on cross zigzag or parallel line so that equal opportunity for each site could be ensured. During survey, a total of 365 plant tissue specimens were treated in lab for isolation of fungi. Among the test specimens, 25 fungi belonging to various species were isolated and five species of fungi were seen to be more frequent. Among the other frequent fungi, Neocosmospora rubicola was found to be a new pathogen associated with potato stem rot. Symptomatic infected plants initially showed water-soaked brown to black lesions on the lower stems, near the collar (Figure 1). With the spread of infection, potato plants gradually wilted and then died. To study the possible pathological causes of this disease, infected potato plants were brought to the Seed and Postharvest Pathology Laboratory, Institute of Agricultural Sciences (IAGS), University of the Punjab, Lahore. Stem sections of $2-3 \mathrm{~mm}^{2}$ healthy control and symptomatic tissues were surfacedisinfected via immersion in $2 \%(\mathrm{w} / \mathrm{v})$ sodium hypochlorite solution for one min followed by three washings with sterile distilled water. Surface sterilized stem sections were dried on sterilized filter paper and then placed aseptically onto Potato Dextrose Agar (PDA) containing Petriplates. Inoculated Petriplates were incubated at $26 \pm 2{ }^{\circ} \mathrm{C}$ and observed regularly for the growth of pathogen. Emerging fungal mycelia from the inoculated stem sections were transferred to fresh PDA Petriplates aseptically for purification.

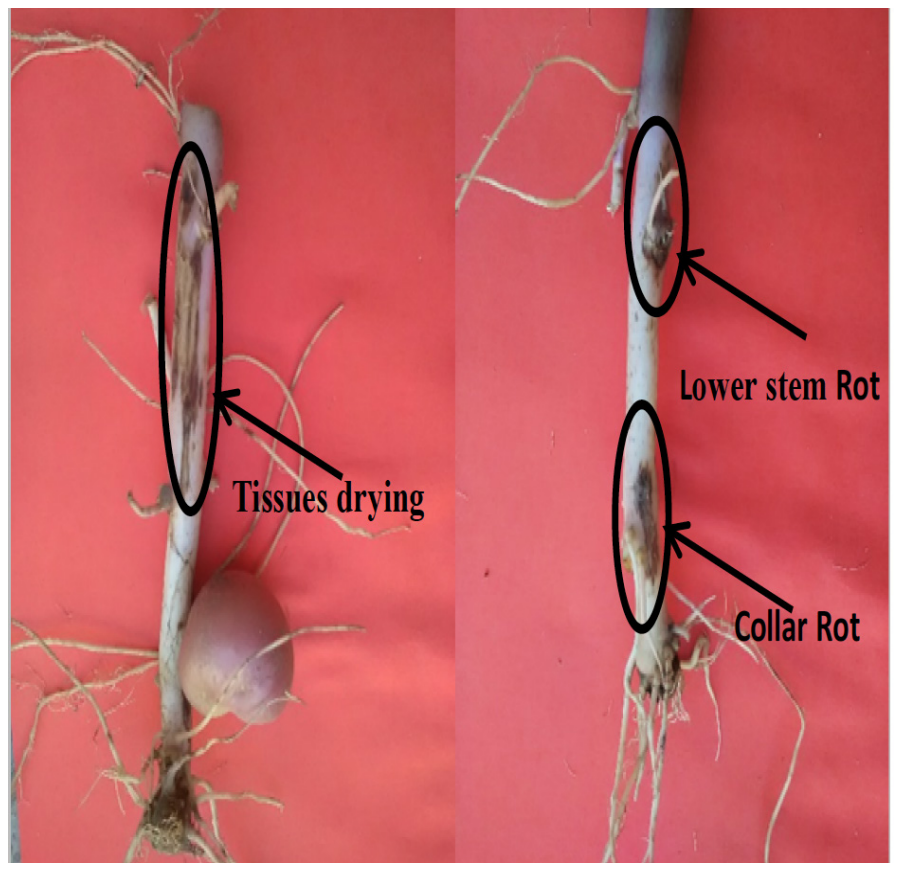

Figure 1: Infection development of $N$. rubicola on potato stem.

To verify the morphology-based identification, the fungi isolates were grown on PDA at $25^{\circ} \mathrm{C}$ for 7 days. For morphology-based study, initially colony characteristics (culture color from front and reverse side, growth pattern, presence of growth zone, colony elevation, presence of submerged or aerial mycelium, types of conidia, presence of water drops or other exudates etc.) were recorded. Microscopic studies were carried out on 3 days to 3 weeks old cultures in water and Trypan blue mounts. Studies on cultural characteristics were initiated on $3^{\text {rd }}$ day showing the appearance of the hyphae, to 21 days till the complete development of conidia. The optical microscope (BOECO; Model BM-120), was used to study of conidia and fungal mycelium. On the basis of morphological features, complete morphological description of fungal strain was prepared. Species were using the authentic taxonomic literature (Leslie and Summerell, 2008).

Genomic DNA of fungal pathogen was isolated using Akhtar et al. (2014) protocol. PCR was executed using subsequent primers; Internal Transcribed Spacer (ITS) of rDNA and partial beta tubulin gene 
(Chowdhary et al., 2019). For the amplification of selected DNA fragments, 5-10 ng total genomic DNA was used as template. PCR amplification was performed in Thermal Cycler in a total volume of $30 \mu \mathrm{l}$ using 2X AmpMasterTM Taq (Gene All Biotechnology Co., Ltd). PCR reactions were carried out following the steps; Initial denaturation at $94{ }^{\circ} \mathrm{C}$ for 5 min followed by 35 cycles of amplification each consisted of $30 \mathrm{sec}$ denaturation at $94^{\circ} \mathrm{C}, 30 \mathrm{sec}$ primer annealing at $55^{\circ} \mathrm{C}, 30 \mathrm{sec}$ amplification at $72{ }^{\circ} \mathrm{C}$ and 7 min final extension at $72{ }^{\circ} \mathrm{C}$. Resulting nucleotide sequences were visualized on a $1.5 \%$ agarose gel for 30 minutes and then PCR products were sequenced by SolGent (Daejeon, Korea). The acquired nucleotide sequences were deposited in GenBank (rDNA-ITS regions ID: MG976818 and partial beta tubulin gene ID: MH016281) and differentiate with the pool nucleotide sequences existing in GenBank by BLAST.

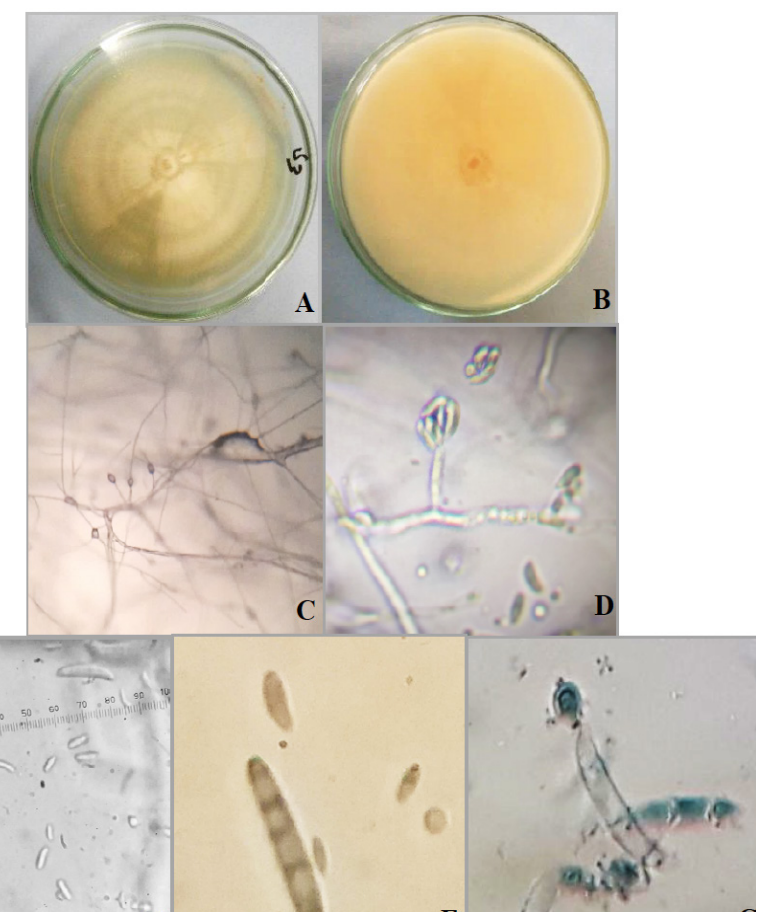

Figure 2: Neocosmospora rubicola (FCBP 1565). A: Colony front; $B$ : Colony reverse: $C$ : Conidial attachment with conidiophores under stereoscope; D: Conidial attachment under $4 X$ magnification of microscope; $E, F$ and $G$ : Conidia.

Phylogenetic tree was aligned by MEGA6 Tamura et al. (2013) using maximum likelihood tree method (Tamura and Nei, 1993). The phylogenetic analysis involved nucleotide sequences of seven different species of Neocosmospora including $N$. rubicola (Lombard et al., 2015) retrieved from GenBank with the nucleotide sequences of respective genes of $N$. rubicola (FCBP1565).
Pathogenicity of isolated fungus was verified by inoculating three weeks old healthy plants with the spore suspension containing both micro and macro conidia of pathogen. Fresh fungus culture was obtained from single spore inoculum on PDA grown for 10 days at $25{ }^{\circ} \mathrm{C}$. Conidial suspension; $3 \times 10^{4}$ conidia $/ \mathrm{ml}$ was made in sterile distilled water and $30 \mu \mathrm{l}$ from this suspension was injected into potato stems approximately $2 \mathrm{~cm}$ above the collar region. Injected areas were covered with sterilized moist cotton and sealed with cellophane tape. Same amount of sterilized water was injected in the stems of three healthy plants to serve as control. Plants were maintained in a green house at $26+2{ }^{\circ} \mathrm{C}$.

\section{Results and Discussion}

Seven days old randomly selected cultures from three different isolates selected and characterized on the basis of cultural and morphological features. Fungal colonies grown on PDA were cream to pale yellow in color on both sides reaching $4-4.5 \mathrm{~cm}$ in diameter in seven days. Colonies were zonate with clear concentric rings, having regular margins without any kind of exudates. These morphological features are closely related with the finding of (Kim et al., 2017). Conidiophores were simple, unbranched, ranging 35-40 $\mu \mathrm{m}$ long. Abundant micro and macro-conidia were present. Macro conidia were cylindrical, curved, 3-4 septate, $8-12 \times 1-2 \mu \mathrm{m}$ in size and aggregated in slimy heads on conidiophores same as in case of Fusarium species. Lombard et al. (2015) reported that Neocosmospora rubicola macroconidia has 3-5-septate, cylindrical, straight or curving at both ends, beaked at both ends, his findings are in agreement with our study. Micro conidia were ellipsoidal to cylindrical in shape, $0-1$ septate, $2-4 \times 1-2 \mu \mathrm{m}$ in size. On the basis of morphology features, causal fungus was identified as Neocosmospora rubicola (Lombard et al. (2015); Zheng at al., 2018). An agar slant of single spore culture of the test pathogen was deposited to First Fungal Culture Bank of Pakistan (FCBP), University of the Punjab under the accession number FCBP1565.

Although important but phenotypic approach of fungal systematics is not sufficient for authentic identification of fungus (Wang et al., 2016). Therefore, molecular data in combination with the morphology are used for identification of fungi (Porras-Alfaro et al., 2014; Javaid et al., 2018). Primer pair ITS1/IT4 amplified approximately $650 \mathrm{bp}$ while that of $\mathrm{Bt}_{2} \mathrm{a} /$ 
$\mathrm{Bt}_{2} \mathrm{~b}$ gave approximately $350 \mathrm{bp}$ DNA fragment. PCR products were visualized on $1 \%$ agarose gel along with DNA size marker and correct amplicons were sent for nucleotide sequencing. Resulting sequences were analyzed by nBLAST for similarity of amplified rDNA-ITS regions (GenBank ID: MG976818) and partial beta tubulin gene (GenBank ID: MH016281). BLAST results indicated that rDNA-ITS and partial beta tubulin gene of present fungal strain were 100\% similar with that of their corresponding sequences of $N$. rubicola strain CBS 320.73 submitted under the accession numbers KM231799 and KM232061. It has been widely accepted that ITS nucleotide sequence in combination with any coding gene, for example, GAPDH, elongation factor or beta tubulin, is useful and accurate way of fungal species identification (Schoch et al., 2012).
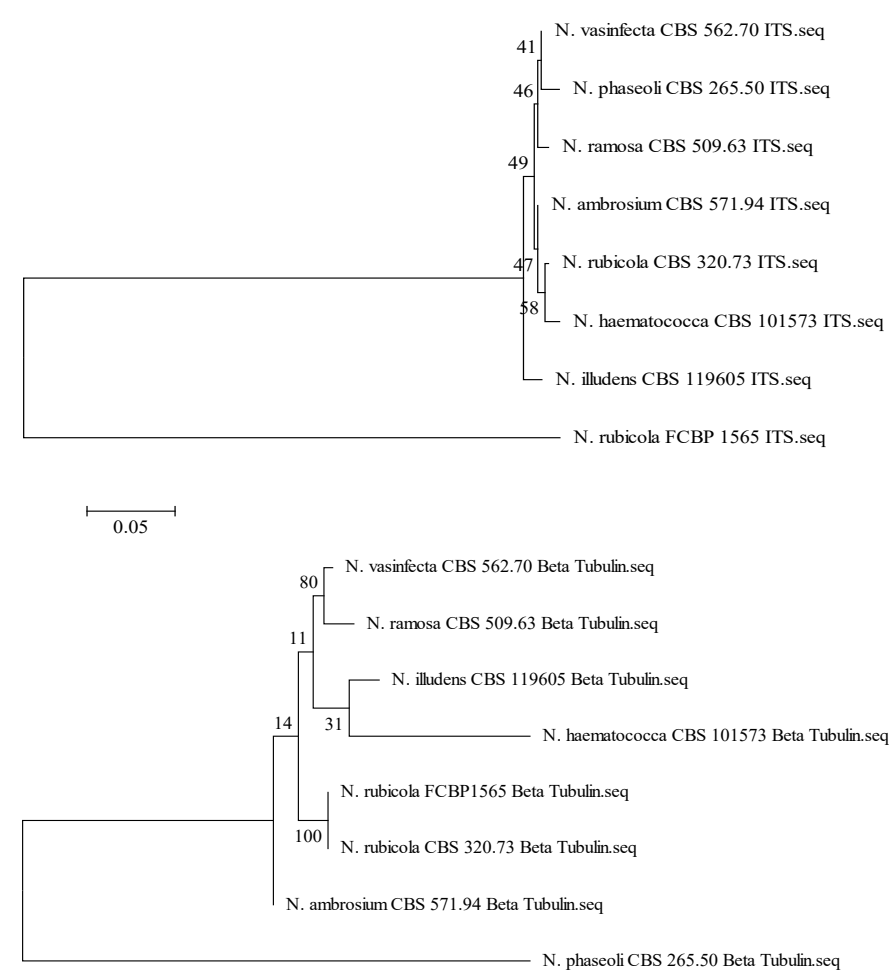

Figure 3: Molecular phylogenetic analysis of ITS (a) and beta tubulin (b) nucleotide sequences.

Phylogenetic tree, based on beta tubulin gene sequence (Figure 3B) depicted 100\% similarity between $N$. rubicola strains CBS 320.73 and FCBP 1565. However, tree based on ITS nucleotide sequence (Figure 3A) exhibited higher similarity of both strains of $N$. rubicola and phylogenetic divergence from other species of the same genus. Hirooka et al. (2012) also apply both phylogenetic and morphological characterizations for the authorization of Neocosmospora species. The clustering percentage of taxa in tree is given next to the branches. The tree branch lengths are measured in term of substitutions per site. Evolutionary divergence between sequences of the strains used for phylogenetic tree analysis was also estimated by MEGA6 using the Maximum Composite Likelihood model (Tamura et al., 2004) and shown in Table 1. The number of base substitutions per site between beta tubulin sequences of CBS 320.70 and FCBP1565 was zero that confirmed the identification of present study pathogen.

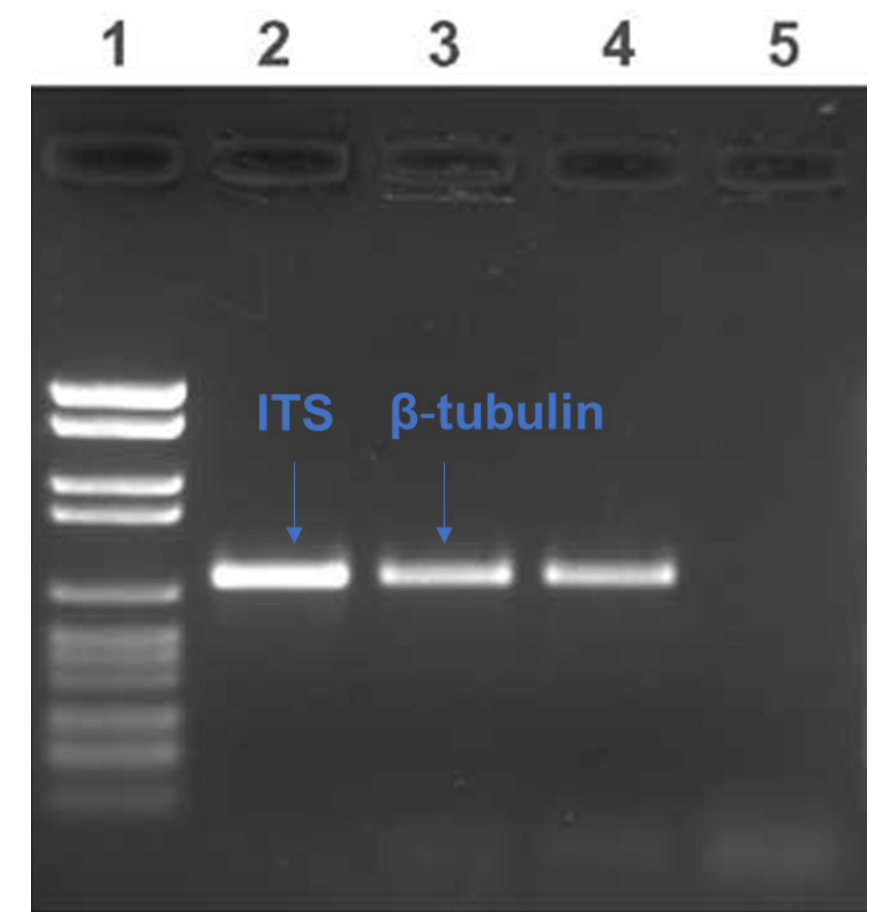

Figure 4: Agarose gel electrophoresis of ITS and beta tubulin PCR products for the differentiation of N. rubicola.

Artificially inoculated stems began to exhibit rotting symptoms after 10 days of injection while control stems remained healthy. Potato plant initially showed browning lesions near the soil line of stem and roots which developed into black resulting in cracking of stem. However, potato seeds in early stage may also be affected and lead to potato plants wilt or stunt growth. The vascular bundles of stem internally changed into light brown to blackish in colour. Therefore, potato plants are defoliated or exhibited chlorotic in leave tissues and in the case of severe infections cause great losses in potato production. $N$. rubicola was re-isolated from lesions of artificially inoculated plants thus satisfying Koch's pathogenicity postulates. Same protocol was followed by He et al. (2016) for confirmation stalk rot of maize. Based on the symptoms, morphological characteristics, molecular and phylogenetic data, $N$. rubicola was reported for the first time from Pakistan causing stem rot in potato plants. 
Table 1: Estimates of evolutionary divergence between nucleotide sequences.



\section{Acknowledgements}

This study was funded by the grant provided by University of the Punjab, Lahore Pakistan to Dr. Salik Nawaz Khan and Dr. Naureen Akhtar.

\section{Novelty Statement}

Neocosmospora rubicola has already been identified as a pathogen on several plants and crops around the world. This disease reports for the first time in Pakistan associated with the potato stem rot. So, our study regarding potato stem rot is unique and first.

\section{Author's Contribution}

MR conceptualized the study, formal analysis, methodology and writing of original draft/ manuscript. NA review and editing, supervision and technical input. SN supervised, reviewed and edited the manuscript. Provided technical guidelines during the study. MS designing of survey format and compilation and interpretation of data. AT field visits for collection of data and Figures and Graphs in Microsoft excel.

\section{Conflict of interest}

The authors have declared no conflict of interest.

\section{References}

Akhtar, N., U. Bashir and S. Mushtaq. 2014. First report of leaf spot of rice caused by Alternaria arborescens in Pakistan. Plant Dis., 98(6): 846846. https://doi.org/10.1094/PDIS-09-130969-PDN

Chowdhary,A.,A.Singh,P.K.Singh,A.Khuranaand J.F.Meis.2019.Perspectives on misidentification of Trichophyton interdigitale/ Trichophyton mentagrophytes using internal transcribed spacer region sequencing: Urgent need to update the sequence database. Mycoses, 62(1): 11-15. https://doi.org/10.1111/myc. 12865

Dastogeer, K.M., H. Li, K. Sivasithamparam, M.G. Jones and S.J. Wylie. 2017. A simple and rapid in vitro test for large-scale screening of fungal endophytes from drought-adapted Australian wild plants for conferring water deprivation tolerance and growth promotion in Nicotiana benthamiana seedlings. Arch. Microbiol., 199(10): 1357-1370. https://doi.org/10.1007/ 
s00203-017-1411-0

He, J., T.L. Yuan and W.H. Tang. 2016. Fusarium graminearum maize stalk infection assay and microscopic observation protocol. Biol. Protoc., 6(23):e2034.https://doi.org/10.21769/ BioProtoc. 2034

Hirooka, Y., A.Y. Rossman, G.J. Samuels, C. Lechat and P. Chaverri. 2012. A monograph of Allantonectria, Nectria, and Pleonectria (Nectriaceae, Hypocreales, Ascomycota) and their pycnidial, sporodochial, and synnematous anamorphs. Stud. Mycol., 71: 1-210. https:// doi.org/10.3114/sim0001

Iqbal, M., S. Ijaz-U1-Hassan, M. M. Hussain, S. Siddiq and M.A. Qureshi. 2019. Studies on potato cyst nematode (Globodera spp.) detection and soil health status in potato core area of Punjab, Pakistan. Plant Prot., 3(1): 21-28. https://doi.org/10.33804/pp.003.01.0114

Javaid, A., G. Shahzad, N. Akhtar and D. Ahmed. 2018. First report of Alternaria leaf spot of broccoli in Pakistan and management of the pathogen by leaf extract of Syzygium cumini, Pak. J. Bot., 50(4): 1607-1614.

Karlovsky, P., M. Suman, F. Berthiller, J. De Meester, G. Eisenbrand, I. Perrin, I.P. Oswald, G. Speijers, A. Chiodini, and T. Recker. 2016. Impact of food processing and detoxification treatments on mycotoxin contamination. Mycotoxin Res., 32(4): 179-205. https://doi. org/10.1007/s12550-016-0257-7

Kim, J.H., D.Y. Kim, H. Park, J.H. Cho and A.H. Eom. 2017. Neocosmospora rubicola, an unrecorded endophytic fungus isolated from roots of Glycyrrhiza uralensis in Korea. Kor. J. Mycol., 45(1): 63. https://doi.org/10.4489/ KJM.20170007

King, J.C. and J.L. Salvin. 2013. White Potatoes, Human Health, and Dietary Guidance. Adv. Nutr., 4: 393S-401S. https://doi.org/10.3945/ an.112.003525

Leslie,J.F and B.A. Summerell.2008. The Fusarium laboratory manual. John Wiley and Sons.

Lombard,L., N.A.,van der Merwe,J.Z. Groenewald and P.W. Crous. 2015. Generic concepts in Nectriaceae. Stud. Mycol., 80: 189-245. https:// doi.org/10.1016/j.simyco.2014.12.002

Majeed, A. and Z. Muhammad. 2018. Potato production in Pakistan: challenges and prospective management strategies a review. Pak. J. Bot., 50(5): 2077-2084.
Nalim, F.A., G.J. Samuels, R.L. Wijesundera and D.M. Geiser. 2011. New species from the Fusarium solani species complex derived from perithecia and soil in the Old-World tropics. Mycologia. 103(6): 1302-1330. https:// doi.org/10.3852/10-307

Porras-Alfaro,A., K.L.Liu, C.R. Kuske and G.Xiec. 2014. From genus to phylum: large-subunit and internal transcribed spacer rRNA operon regions show similar classification accuracies influenced by database composition. Appl. Environ. Microbiol., 80: 829-840. https://doi. org/10.1128/AEM.02894-13

Schoch, C.L., K.A. Seifert, S. Huhndorf, V. Robert, J.L. Spouge, C.A. Levesque, W. Chen and Fungal Barcoding Consortium. 2012. Nuclear ribosomal internal transcribed spacer (ITS) region as a universal DNA barcode marker for Fungi. PNAS. USA, 109: 6241-6246.

Shahzadi, L., A. Bashir, S.N. Khan, M. Riaz, M.H. Shah, Z. Nawaz and A. Tahir. 2020. Influence of abiotic factors on growth and sporulation of Neocosmospora rubicola associated with stem rot of potato in Punjab, Pakistan. Mycopath. 16(2): $87-90$.

Tamura, K and M. Nei. 1993. Estimation of the number of nucleotide substitutions in the control region of mitochondrial DNA in humans and chimpanzees. Mol. Biol. Evol., 10: 512-526.

Tamura, K., G. Stecher, D. Peterson, A. Filipski and S. Kumar. 2013. MEGA6: Molecular evolutionary genetics analysis version 6.0. Mol. Boil. Evol., 30: 2725-2729. https://doi. org $/ 10.1093 / \mathrm{molbev} / \mathrm{mst} 197$

Tamura, K., M. Nei and S. Kumar. 2004. Prospects for inferring very large phylogenies by using the neighbor-joining method. PNAS USA. 101: 11030-11035. https://doi.org/10.1073/ pnas.0404206101

Tang,X.M., T.Y.Lin, S.S.Zhou, G.F.Li, P.Liu,Z.F. Ye and L.W.Zhu. 2017. Pathogen identification of root rot in pear plant and fungicide screening for its efficient control. JNAU. 40(1): 76-83.

Wang, Z., R.H. Nilsson, T.Y. James, Y. Dai and J.P. Townsend. 2016. In biology of microfungi. Springer, pp. 25-46. https://doi. org/10.1007/978-3-319-29137-6_3

White, T.J., T. Bruns, S. Lee and J.W. Taylor. 1990. Amplification and direct sequencing of fungal ribosomal RNA genes for phylogenetics. In: 
Innis MA, Gelfand DH, Sninsky JJ, White TJ (eds) PCR protocols: a guide to methods and applications. Acad. Press, San Diego. pp. 315-322. https://doi.org/10.1016/B978-0-12372180-8.50042-1

Zheng, F., G. Xu, F.Q. Zheng, X.F. Ding and C.P. Xie. 2018. Neocosmospora rubicola Causing Stem Rot of Pitaya (Hylocereus costaricensis) in China. Plant Dis., 102(12): 2653-2653. https:// doi.org/10.1094/PDIS-09-17-1469-PDN 